\title{
The reformers' dilemma: media, policy ownership, and reform
}

\author{
Peter T. Leeson · Christopher J. Coyne
}

Published online: 6 July 2007

(C) Springer Science+Business Media, LLC 2007

\begin{abstract}
Current proposals for strengthening policy ownership in reforming economies are fundamentally flawed. Modeling the reform process as a prisoners' dilemma demonstrates that political agents must overcome this conflict of interests before present proposals for bolstering ownership will work. A politically autonomous mass media is one important mechanism enabling political agents to do this. Reforming countries without free media face an uphill battle overcoming the problems associated with transition. We test our theory by investigating the relationship between media freedom, foreign aid, and economic development in 26 post-socialist transition countries. The results of this analysis support our theory.
\end{abstract}

Keywords Media $\cdot$ Reform $\cdot$ Policy ownership

JEL Classifications $\mathrm{O} 17 \cdot \mathrm{O} 12 \cdot \mathrm{P} 16 \cdot \mathrm{K} 20$

\section{Introduction}

The trouble of transition is among the most important economic topics of the 21st century. Since 1989, some nations, like Estonia, Poland and the Czech Republic, have reformed quite successfully. Others, like Bulgaria, Belarus and Turkmenistan, remain in relative poverty. Why have some post-socialist nations performed relatively well while others have not?

\footnotetext{
P. T. Leeson $(\square)$

Department of Economics, West Virginia University, P.O. Box 6025, Morgantown, WV 26506-6025, USA

e-mail: ptleeson@mail.wvu.edu

C. J. Coyne

Department of Economics, Hampden-Sydney College, Hampden-Sydney, VA 237943, USA
} 
In attempting to answer this question the development community has increasingly pointed to the importance of " policy ownership." According to this concept, political leaders inside transitioning countries that receive foreign aid must be genuinely committed to policy change for new policy to be implemented. A recent literature proposes giving greater policy latitude to foreign aid recipients in reforming nations as a means of strengthening ownership (see for instance, Kahn and Sharma 2001; IMF 2001; Ebas 2003; Goldstein 2000a).

The factors contributing to the success or failure of transitioning economies are many and complicated. Here we aim to analyze only one important component underlying reform success or failure-mass media. While some has recently been written on the relationship between media and economic outcomes (Coyne and Leeson 2004; Leeson and Coyne 2005; Leeson 2007; Besley and Prat 2006; Besley and Burgess 2002; Djankov et al. 2002, 2003), no one has analyzed the impact of media on policy ownership in reform. ${ }^{1}$

To do this, we use a simple theoretical framework that models the reform process as a prisoners' dilemma game we call the "Reformers' Dilemma." Our core thesis is two-fold. First, proposals for strengthening ownership that do not first resolve the Reformers' Dilemma are unlikely to work. Second, without an independent mass media to act as an effective enforcement mechanism, politicians are unlikely to own policy. They will use aid distributed by bilateral and multilateral donors to benefit themselves at the expense of the public, hampering economic development.

To test our theory we examine the relationship between media freedom, foreign aid, and economic development in the post-socialist transition countries. The results of this analysis support our theory. We find that media freedom is associated with improved economic development, while media dependence is associated with lower economic development. Additionally, we find that foreign aid is positively connected to economic development only in countries with relatively free media. In countries without free media, additional foreign aid is associated with a reduction rather than improvement in average income.

The remainder of this paper is organized as follows. Section 2 elaborates our analytical framework using the Reformers' Dilemma. Section 3 considers mass media's role in resolving this dilemma. Section 4 empirically examines our theory. Section 5 concludes.

\section{The reformers' dilemma: Why self-interested politicians don't own policy}

Current approaches to strengthening ownership emphasize the need to make the policy-devising process more participatory or inclusive of foreign aid recipients. The intuition here is straightforward. If political leaders in transitioning countries have more say in how the aid they receive is used, for example through which policies are adopted and how they are implemented, they are more likely to genuinely support change and undertake reform.

\footnotetext{
1 Sen $(1984,1999)$ was the first do this in noting the importance of an independent media in preventing the occurrence of famines.
} 
One suggestion under this rubric emphasizes encouraging reforming nations to design their own programs and policies (IMF 2001). Related to this proposal is that of offering politicians a menu of options, devised by the lending institution, to choose from in using aid to undertake reform. Similarly, it has been suggested that structural conditionality be "streamlined," giving aid recipients broader/fewer mandates within which they may tailor policy as they see fit, rather than compelling compliance with relatively specific reform mandates (Erbas 2003; Bird 2001; Collier and Gunning 1999). Kahn and Sharma (2001) have suggested allowing leaders flexibility in the timing of policy implementation. Additionally, outcomebased conditionality, which attaches continued foreign aid to outcomes rather than compliance with policy/program implementation, has been proposed on similar grounds (Kahn and Sharma 2001; Goldstein 2000a; Spraos 1986).

To assess the likely effectiveness of these proposals, we model the reform process as a prisoners' dilemma situation. This framework captures the essential features of interaction between political agents in reforming nations. In our framework there are two key players, political agents, who may either use aid to "own policy" -i.e., undertake socially beneficial reform, or use aid to cater to special interest groups. Figure 1 depicts this game, which we call the Reformers' Dilemma. $^{2}$

Although this game only has two players, it reflects three sets of interests: the interests of political agent 1, the interests of political agent 2, and the interests of citizens. ${ }^{3}$ The private payoffs to political agents are in the upper left-hand corner of each box and are $a, b, b / 2$ and 0 , where $b>a>b / 2>0$. The lower right-hand corner of each box contains the payoffs to society in each case, $X$ and $Y$, where $X>Y$. When both agents use aid to own policy, both receive some payoff, $a$, in the form of revenue generated from taxing a high level of social wealth. In this case social wealth is maximized and society's payoff is $X$.

However, this revenue is less than each agent could receive by using aid to cater to special interest groups when the other agent does not, $b$. When only one agent caters to special interest groups this agent receives all the gains from catering while

Fig. 1 The reformers' dilemma

\begin{tabular}{|c|c|c|c|}
\hline & & Political & Agent 1 \\
\hline & & Own Policy & $\begin{array}{l}\text { Cater to Special } \\
\text { Interests }\end{array}$ \\
\hline liticol A gent? & Own Policy & $(a, a)$ & $(0, b)$ \\
\hline Political Agent 2 & $\begin{array}{l}\text { Cater to Special } \\
\text { Interests }\end{array}$ & $(b, 0)$ & $(b / 2, b / 2)$ \\
\hline
\end{tabular}

\footnotetext{
${ }^{2}$ Leeson (2006) has used this framework to explain why even partially-benevolent politicians under democracy fail to deliver social welfare enhancing policy.

3 Though we do not model them explicitly, this game also reflects the interest of special interest groups, which are benefited equally when one or both political agents cater to them, and are harmed when both political agents own policy.
} 
the other receives zero. Because policy is tailored to special interests rather than maximizing social wealth, the public receives a lower payoff, $Y$.

When both agents utilize aid to cater to special interests, each receives gains from catering, but the total gains are divided and each agent receives a payoff of only $b / 2$. At any given point in time the number of rents available for 'offering' by politicians to special interests is fixed. The same 'amount' of special interest catering thus occurs whether one or both agents engage in the practice. So, although the spoils are distributed differently, the negative effect that using aid to tailor policy to special interests has on social wealth is the same in either case, leading again to a public payoff of $Y$.

To imagine this last point more clearly, consider the following example. Social wealth is damaged equally if one political agent uses foreign aid to subsidize two farmers in the amount of $\$ 1$ million each and the other subsidizes no one, or if one political agent subsidizes one farmer for $\$ 1$ million and the other political agent subsidizes the other farmer for $\$ 1$ million. Although political agents' individual payoffs are different in each case-in the first case $(2,0)$ and in the second case $(1$, 1) - the net cost to society is $\$ 2$ million in both events.

As our figure illustrates, political agents' dominant strategy is to use aid to cater to special interests. This equilibrium is not only suboptimal for the agents, but for society as well. Both political agents and the public would be made better off by moving to the 'own policy-own policy' equilibrium. Analyzing the proposals for strengthening ownership that we considered above in light of this framework yields an important insight. Namely, these proposals are unlikely to work. ${ }^{4}$ They are indeed capable of strengthening ownership, but only once a solution to the Reformers' Dilemma has already been found.

If political agents are able to overcome the Reformers' Dilemma and use foreign assistance to mutually work towards implementing good policy, then additional latitude may enhance their support of reform changes. For instance, a politician inclined to balance the budget may be more likely to support this end if given the choice over reducing spending or increasing taxes in order to achieve it. In this event, the proposals we looked at may strengthen agents' position in the 'own policy-own policy' equilibrium.

However, if political agents have not overcome the Reformers' Dilemma, then proposals aimed at giving them additional latitude with the aid they receive will result in potentially worse policies, not better. Giving greater policy control to political agents who use foreign aid to cater to special interests only enhances their ability to do so. For instance, politicians who rely on steel manufacturers for election support may use their increased policy control to implement higher

\footnotetext{
${ }^{4}$ One proposal not discussed here is pre-selection (see, for instance, Dollar and Svensson 2000; Drazen 1999; Kenen 2000; Williamson 2000; Goldstein 2000b; Burnside and Dollar 2000; Collier, Dollar and Stern 2000; Meltzer et al. 2000). Pre-selection amounts to pre-selecting those countries eligible for aid on the basis of their track records for implementing good polices under the belief that they will continue to do the same in the future, therefore owning policy. We do not address pre-selection because it is not a suggestion aimed at giving more policy control to indigenous politicians. It is worth noting, however, that to the extent that nations with good policies perform the best, this suggestion has the obvious drawback of making assistance available only to those countries that need it least, while making it unavailable to those that need it most.
} 
tariff protection. In this case, greater latitude is likely to fortify political agents' position in the 'cater to special interest-cater to special interest' equilibrium, reinforcing the suboptimal outcome.

Absent a solution to the Reformers' Dilemma, we would get better policies by strengthening conditionality, not weakening it. For example, if we know that politicians are interested in inflating around election times to 'heat up' the economy and boost their reelection chances, we would minimize their ability to do so by limiting their control over the timing of monetary injections rather than increasing it. Likewise, unless the Reformers' Dilemma has been overcome, we would do more to prevent damage to social welfare by reducing foreign assistance rather than increasing aid to reforming nations. For instance, if we know that political actors use foreign aid flows to reward their friends and allies at the expense of the public, we would minimize their ability to do so by curtailing aid rather than offering more. Policy ownership, therefore, requires first and foremost a solution to the Reformers' Dilemma.

Fortunately, the real-world Reformers' Dilemma does not correspond precisely to the strictures required in the game-theoretic model (Tullock 1999). In the real world, play may be repeated, players may select their partners, and players can communicate. The absence of these features makes the game-theoretic dilemma insurmountable. But in the real world, it is precisely through these avenues that we can find a solution.

\section{Mass media as a monitoring mechanism}

To overcome the Reformers' Dilemma through repeated play there must be some mechanism for both detecting and punishing defecting political agents-those who cater to special interests instead of owning policy. When media is independent from government it can serve as a powerful mechanism towards this end. An autonomous mass media performs two crucial functions in this capacity.

First, a free media makes monitoring the behavior of politicians significantly easier and less costly. For instance, in the United States, where media is largely free from the state, journalists frequently find it in their interest to report information on the corrupt, deceitful, or questionable activities of politicians. Rep. Jim Traficant, Whitewater, Iran-Contra, and more recently, President G.W. Bush's claims regarding weapons of mass destruction in Iraq are just a few examples illustrating this. Also, media outlets attend more political events than the typical voter and are generally more knowledgeable about the activities of political actors than the average citizen. Due to these factors, the public is more likely to learn about politicians' bad behavior and finds it less costly to do so because of media.

An independent media also enables political agents to monitor each other better. For instance, when Bush Sr. broke his tax pledge, the Democrats were among the first to report this to the public. Media-covered election campaigns in the US are largely exercises in politicians from opposing camps 'telling on' one another to the public about the things their opponent did or did not do during their time in office. In 
this way, a free media facilitates politicians' ability to mutually hold one another accountable to the public. ${ }^{5}$

Secondly, a free media contributes to overcoming the Reformers' Dilemma by enabling citizens to more effectively use punishment mechanisms to discipline political defectors. Independent media sources are more likely to convey credible information about the activities of political actors to the public. On the one hand, these media sources are subject to the 'market test.' To the extent that citizens value accurate information about the activities of political agents, those media outlets that do a better job of providing such information will tend to flourish. Those that do not will tend to fail. On the other hand, where the media is privately owned, government finds it more difficult to manipulate the content of political news. Both of these features of an independent media encourage 'honest reporting,' which arms citizens with information they can use to punish defecting political agents through voting, financial support, or in the extreme, calls for removal from office. For example, the public used information about Watergate, first discovered and presented by a journalist, to demand the resignation of Richard Nixon. The recall of Gov. Jim Davis in California provides another case in point. To avoid bad press and the voters' wrath that comes with it, political agents face pressure to consider the public's interests in addition to their own. Free media, therefore, provide political actors with an incentive to cooperate on the 'own policy-own policy' equilibrium.

Of course, even in countries with very high levels of media freedom, like the United States, the media is not a perfect mechanism for preventing political agents from defecting. First, even in these countries, the media is never perfectly autonomous from the government. Media-related taxes, regulations, and licensing, for example, are common features of the policy environment even where the media is highly free. As we discuss below, these factors give government some leverage over media outlets in nearly all countries, which can undermine the credibility of media-provided information. Second, even in countries where the media is highly free, the structure of the media market can also weaken media's ability to reveal relevant information about politicians' activities to voters. In the United States, for example, some observers contend that the gradual disappearance of local newspapers, and substitution with national newspapers, has reduced competition important to compelling papers to report information objectively. ${ }^{6}$ Despite these imperfections of the media monitoring mechanism, as we highlight below, the effect of a freer media on the accuracy of the information it provides relative to one that is less free is clear. A free media contributes to the revelation of information that

\footnotetext{
5 An independent media also prevents political actors from lying about one another. Autonomous, competitive media sources risk losing their reputation if they report false information about members of one party conveyed to them by members of another. An independent media thus checks politicians' desire to start damaging rumors about one another.

${ }^{6}$ Media bias could also emerge even where it is fully privatized if citizens demand news that conforms to their priors, or if media outlet owners are interested in presenting their perspective, even though it will cost them in the marketplace. As discussed above, the presence of stiffer competition tends to mitigate these factors, but a certain degree of bias is still possible. See, for instance, Goldberg (2003) who discusses the American media industry's left-leaning political bias and manipulation of information as a means of influencing political outcomes, such as the reelection of George W. Bush. For more on the leftleaning political bias of American mass media see, for example, Kuypers (2002).
} 
voters can use to hold defecting political agents accountable. For an unfree media, this is not the case.

So far we have only discussed the benefits that flow from a free media. Alternatively, mass media may be heavily dependent upon the state. In this case government is able to exert considerable pressure regarding the substance of information conveyed through mass media. The state has two vehicles through which it exerts political influence where media is not free. First, the state may financially pressure media sources. For instance, the state may forgive a media outlet's debts or taxes owed in return for the media outlet's agreement to only cover stories that flatter the ruling party.

Second, the state may control the structure of the media industry itself. For instance, the government may explicitly own and control major television stations, radio stations or newspapers. The state may also own and control necessary media inputs, for example, newsprint mills or newspaper distribution networks. Government might also control the structure of the media industry through subsidizing particular media outlets, or through imposing barriers to entry into the media industry. For instance, the state may require a license to produce magazines or newspapers, or to broadcast television or radio programs.

Both types of political influence compromise the ability of media sources to effectively monitor and report the activities of defecting political agents. Defecting politicians prefer to keep the public in the dark about their activities. If political agents control the flow of information-either through financial control of media outlets or through controlling the media industry's structure-they will use this power to keep information about their behavior hidden. For instance, politicallycontrolled television channels may be instructed not to report particular events that reflect badly on those in power. In this case, politicians in the controlling party may also use the media to smear the opposition. For example, they may pressure media outlets to communicate false reports to the public about an opponent's activities. Alternatively, politicians in the ruling party may use their influence over media sources to decidedly advantage members of their party in the press. For instance, majority party members may receive disproportionate coverage in the media compared to the opposition.

The inaccuracy or incompleteness in media coverage, due to dependence upon the state, compromises the ability of citizens to punish defectors. On the one hand, if citizens are unaware of political agents' behavior because government prevents this information from reaching them, they cannot effectively punish defection. On the other hand, if citizens are aware that mass media sources are biased, they will tend to discount the information they receive through mass media. Without reliable information, citizens cannot punish defection. Thus, society's ability to overcome the Reformers' Dilemma is largely constrained by media's relationship to the state. ${ }^{7}$

\footnotetext{
7 Elsewhere we have examined the "credibility crisis" that results from media's dependence upon government. See, Leeson and Coyne (2005).
} 


\section{Media freedom and the productivity of foreign aid}

To test our theory we investigate the relationship between media freedom, foreign aid, and economic development. Our theory predicts two main results. First, greater media freedom will be associated with higher levels of economic development. Lower media freedom will be associated with a lower level of development. Second, the Reformers' Dilemma predicts that foreign aid will be of little help for economic development in countries that do not have free media because in these countries there is no functioning mechanism to monitor politicians' behavior or to hold them accountable if they create policy that caters to special interest groups instead of promoting the general welfare. In fact, our theory indicates that increasing aid in nations without free media may actually worsen economic development since in these places more aid translates into increased capacity of predatory politicians to pursue activities that benefit themselves at the expense of the public. Conversely, in countries where the media is independent of the government, citizens can use the media as a tool to monitor and punish deviant political actors. As such, foreign aid is more likely to contribute to economic advance. Our theory therefore predicts that greater media freedom will increase the productivity of foreign aid.

To test these hypotheses we proceed in several steps. First we examine the relationship between media freedom and economic development in transition economies. We do this in the context of the post-socialist transition countries, since these nations are in the midst of a reform process like that described above in making the move from centrally-planned economies to market-oriented ones. These countries also face reform obstacles rooted in politicians' decisions to own policy by pursuing activities that will enhance public welfare, or to cater to special interest groups to benefit themselves at the expense of the public. The post-socialist transition countries therefore provide an excellent test group to determine the impact of media freedom on economic development. We consider all post-socialist countries for the year 2004 with the exception Serbia and Montenegro, for which data are not available, giving us a sample of 26 countries. ${ }^{8}$ Although our data cover nearly all post-socialist countries, our sample size is admittedly limited. As with all empirical tests, here too it is therefore important to use caution when drawing inferences from the results.

Our data come from two sources. Income data are from the World Bank's World Development Indicators (2006) and media freedom data come from Freedom House's (2005) media freedom index. This index assigns points to countries on the basis of three equally-weighted categories related to media's independence from government to create a composite score of media freedom which we have rescaled to range from zero (totally unfree) to 100 (totally free). The categories it considers are legal environment, which looks at laws, statues, constitutional provisions and regulations that enable or restrict the media's ability to operate freely in a country; political environment, which evaluates the degree of political control over the content of news media in each country (such as editorial independence, official or

\footnotetext{
${ }^{8}$ The former East Germany is a special case in that it has been integrated into Germany, a marketoriented economy. For this reason, we do not consider Germany.
} 
unofficial censorship, harassment or attacks against journalists, etc.); and economic environment, which includes the structure of media ownership, media-related infrastructure, its concentration, the impact of corruption or bribery on news media content, and the selective withholding or bestowal of subsidies or other sources of financial revenue on some media outlets by the state. Media considered by this index include TV, radio, newspaper, and the Internet.

Figure 2 investigates the relationship between media freedom and GDP per capita (PPP constant 2000 US\$) for the post-socialist transition countries.

The relationship between media freedom and per capita GDP in these reforming economies is strong and positive, as our framework predicts. In a simple ordinaryleast squares (OLS) regression that looks at this relationship econometrically, the effect of media freedom on average income is large, positive, and highly significant $(t$-stat $=6.15)$. In the benchmark equation that looks only at the relationship of media freedom to average income, media freedom explains 60 percent of the variation in GDP per capita among the post-socialist transition countries. A one percent increase in media freedom is associated with a $\$ 159$ increase in per capita GDP. Though we do not show it here, the strength of this relationship between media freedom and average income also holds for other countries and controlling for other factors that impact per capita GDP (see Djankov et al. 2003).

Next we seek to examine the connection between media freedom and economic development through foreign aid. Specifically, we want to determine what relationship, if any, foreign aid has with average income in the post-socialist transition countries when media are controlled by government versus when media are free. We use data from the World Bank's World Development Indicators (2006) for information on per capita GDP and foreign aid per capita, and use Freedom House's (2005) media freedom index to measure media freedom. Specifically, we estimate the following equation:

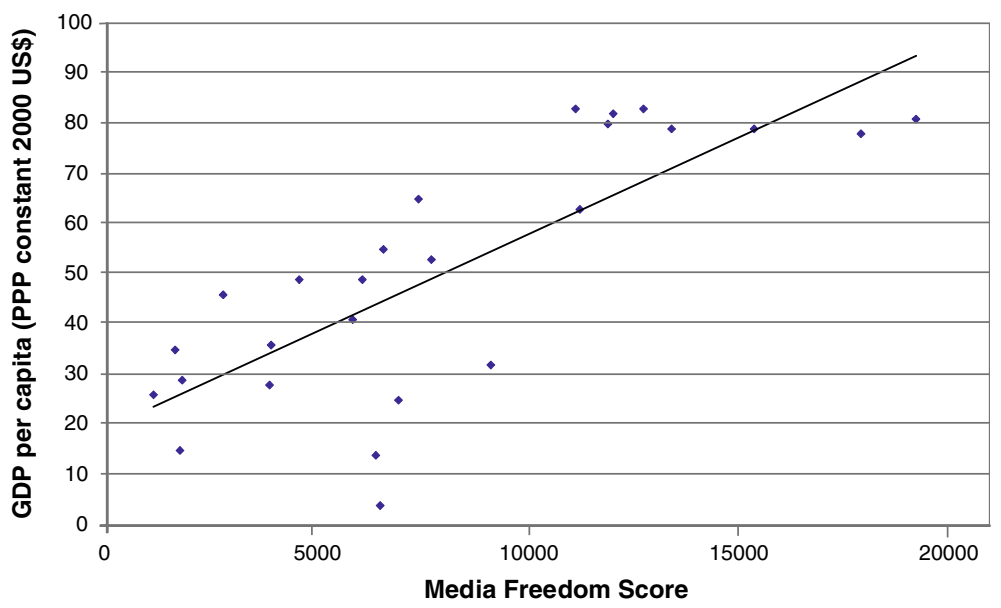

Fig. 2 Media freedom and economic development 


$$
\begin{aligned}
\text { GDP per capita }= & \alpha+\beta_{1} \text { Media Freedom }+\beta_{2} \text { Aid per capita } \\
& +\beta_{3} \text { Media Free } * \text { Aid per capita }+\beta_{4} \text { OECD }+\varepsilon
\end{aligned}
$$

where GDP per capita is a country's per capita GDP in constant 2000 PPP US\$, Media Freedom measures media's independence from government in each of the transition countries, Aid per capita measures aid per capita in each country, and OECD is a binary variable equal to one when a country is a member of the OECD and zero otherwise. We control for OECD membership to ensure that our results are not driven by a small number of post-socialist transition nations, such as the members of the Visegrad Group, which are substantially wealthier than the others and have high levels of media freedom (Leeson and Trumbull 2006). Finally, we construct an interaction variable, Media Free*Aid per capita, which measures foreign aid's connection to per capita GDP through the channel of media. If our argument is correct, the coefficient on media freedom should be positive, on aid should be zero or negative, and on the interaction term should be positive.

Since we only have a cross-section of countries, our results cannot be decisively interpreted as causal. In particular, in addition to media freedom impacting GDP per capita, GDP per capita may also influence the extent of media freedom. Although, following others such as Djankov et al. (2003), we emphasize the role of media in promoting economic development, we must not overlook the role that effective policies play in promoting an effective media. For example, while a free media encourages political agents to make socially-improving policy changes, it is also true that where such policies exist, it is easier for media sources to become free. Thus, the arrow of causality runs in both directions. Nevertheless, finding the relationships discussed above would support the theory that media freedom enhances economic development, foreign aid alone does not enhance economic development and, conditional on having a high level of media freedom, foreign aid enhances economic development-i.e., media freedom makes foreign aid more productive. The results of this regression performed using OLS are contained in Table 1.

The results in Table 1 support our theory. The relationship between media freedom and GDP per capita in the post-socialist transition countries is large, positive, and significant. A one percent increase in media freedom is associated with an additional $\$ 118.60$ in average income. Foreign aid is negatively associated with GDP per capita by itself. However, conditional on having a high level of media

Table 1 Media freedom, aid, and economic development

Notes: Regressand: GDP per capita. Calculated using OLS, standard errors in parentheses. ** Significant at 5\% level;

* significant at the $18 \%$ level

\begin{tabular}{ll}
\hline Regressors & \\
\hline Media freedom & $118.60^{* *}(45.87)$ \\
Aid per capita & $-104.52^{* *}(50.52)$ \\
Media free*aid & $1.33^{*}(0.96)$ \\
OECD & $2316.24(2052.21)$ \\
$R^{2}$ & 0.74 \\
Observations & 26 \\
\hline
\end{tabular}


freedom, foreign aid's relationship to average income is positive. The coefficient on our interaction term is positive and significant at the 18 percent level. This is not as significant as media freedom or aid by itself (both of which are significant at the five percent level), but is reasonable given the small size of our sample, which covers only 26 countries.

Next, we run the same regression, this time controlling for membership in the Baltic community instead of the OECD. Specifically, we estimate:

$$
\begin{aligned}
\text { GDP per capita }= & \alpha+\beta_{1} \text { Media Freedom }+\beta_{2} \text { Aid per capita } \\
& +\beta_{3} \text { Media Free } * \text { Aid per capita }+\beta_{4} \text { Baltic }+\varepsilon
\end{aligned}
$$

where GDP per capita is a country's per capita GDP in constant 2000 PPP US\$, Media Freedom measures media's independence from government in each of the transition countries, Aid per capita measures aid per capita in each country, Media Free*Aid per capita measures foreign aid's connection to per capita GDP through the channel of media, and Baltic is a binary variable equal to one when a country is a Baltic state and zero otherwise. The Baltic countries have very high media freedom, relatively high incomes, and receive very high per capita foreign aid. To get an idea of this, the mean media freedom, per capita GDP, and per capita foreign aid for our whole sample are $43.77, \$ 8041.58$, and $\$ 50.38$ respectively. The mean for these variables in the Baltic states are 82.67, \$11990.51, and $\$ 73.04$ respectively. The Baltic countries therefore have the potential to skew regression results that do not control for their presence. For this reason, we include a dummy to account for them. The results of this estimation are reported in Table 2.

The results are essentially the same but in this specification grow stronger. Notably, the coefficients on media freedom and aid per capita grow larger (in absolute terms) and more significant. When membership in the Baltic community is controlled for, both grow in significance to the one percent level. The coefficient on our interaction variable also grows, and importantly, its significance does as well. When the Baltic dummy is included, the relationship between aid per capita and per capita GDP through the channel of media becomes significant at the five percent level.

On the basis of the estimates in Table 1 and Table 2 it is possible to calculate the threshold of media freedom past which the impact of foreign aid on per capita GDP becomes positive. To do this we simply divide the coefficient on Aid per capita by

Table 2 With Baltic Dummy

Notes: Regressand: GDP per capita. Calculated using OLS, standard errors in parenthases. *** Significant at $1 \%$ level;

** significant at the 5\% level;

* significant at the $10 \%$ level

\begin{tabular}{ll}
\hline Regressors & \\
\hline Media freedom & $128.50^{* * *(37.08)}$ \\
Aid per capita & $-173.19^{* * *}(64.20)$ \\
Media free*aid & $2.61 * *(1.25)$ \\
Baltic & $-4925.55^{*}(2743.16)$ \\
$R^{2}$ & 0.76 \\
Observations & 26 \\
\hline
\end{tabular}


the coefficient on our interaction term. Using the estimates from Table 1 this gives us: $\beta_{2} / \beta_{3}=78.58$. Using the estimates in Table 2 delivers essentially the same result: $\beta_{2} / \beta_{3}=66.36$. For countries with media freedom levels below this threshold, an increase in foreign aid is associated with a decrease in per capita GDP. For countries with media freedom levels above this threshold, an increase in foreign aid is associated with an increase in per capita GDP. Since media freedom ranges from zero to 100 , a relatively free media is therefore required before additional aid exhibits a positive connection to average income. To put this in perspective, the United States scores an 83 on the media freedom index (Freedom House 2005). Thus, among the post-socialist transition countries at least, there seems to be substantial evidence supporting our theory about media freedom, policy ownership and reform.

\section{Conclusion}

Our analysis based on the Reformers' Dilemma has important implications for transition and economic growth. First, it suggests that while policy ownership is a crucial component to successful transition, current proposals for strengthening ownership are unlikely to work. Giving additional policy control to political actors in aid-receiving nations may be helpful, but only once society has overcome the Reformers' Dilemma. Absent a solution to this problem, increasing the latitude offered to indigenous politicians is likely to result in worse policies, not better. Similarly, our empirical analysis suggests that foreign aid is ineffective until countries reach a relatively high level of media freedom. Media freedom is associated with increased productivity of aid, but additional aid is associated with improved economic development only once a critical threshold of media freedom has been passed. Below this threshold, additional aid, in giving greater power to political actors who have not overcome the Reformers' Dilemma, gives these actors increased ability to benefit themselves at the expense of society, harming rather than improving economic advance. These findings imply that development community efforts would be best spent creating an environment in which independent media sources can flourish in reforming countries before doling out assistance or tackling more policy oriented issues.

Additionally, our analysis implies that media autonomy-a feature typically considered an amenity of wealthy nations rather than a critical component to achieving wealth is considerably more important to creating economic prosperity than it seems at first glance. An independent mass media significantly eases the monitoring of political agents and enables a mechanism, through media consumers, for punishing political defectors who refuse to own policy. On the other hand, when media is dependent upon government, media-provided information is subject to political manipulation, rendering it unreliable. This eliminates citizens' ability to monitor and punish political agent defection. Politicians who are aware of this capitalize on voter ignorance by serving their own interests at the expense of society. 
Acknowledgments We thank Peter Boettke, Russell S. Sobel, and an anonymous referee for helpful comments and suggestions. Leeson was a Visiting Fellow at Harvard University when this research was conducted. We would like to thank the Mercatus Center and Earhart Foundation for financial support.

\section{References}

Besley, T., \& Burgess, R. (2002). The political economy of government responsiveness: Theory and evidence from India. Quarterly Journal of Economics, 117, 1415-1452.

Besley, T., \& Prat, A. (2006). Handcuffs for the grabbing hand? Media capture and government accountability. American Economic Review, 96, 720-736.

Bird, G. (2001). IMF programmes: Is there a conditionality laffer curve? World Economics, 2, $29-49$.

Burnside, C., \& Dollar, D. (2000). Aid, policies, and growth. American Economic Review, 90, 847-868.

Collier, P., Dollar, D., \& Stern, N. (2000). Fifty years of development. Mimeo: World Bank.

Collier, P., \& Willem Gunning, J. (1999). The IMF's role in structural adjustment. Economic Journal, 109, F634-F651.

Coyne, C. J., \& Leeson, P. T. (2004). Read all about it! understanding the role of media in economic development. Kyklos, 57, 21-44.

Djankov, S., La Porta, R., Lopez-de-Silanes, F., \& Shleifer, A. (2002). The regulation of entry. Quarterly Journal of Economics, 117, 1-38.

Djankov, S., McLiesh, C., Nenova, T., \& Shleifer, A. (2003). Who owns the media?. Journal of Law and Economics, 46, 341-382.

Dollar, D., \& Svensson, J. (2000). What explains the success or failure of structural adjustment programs? Economic Journal, 110, 849-917.

Drazen, A. (1999). What is gained by selectively withholding foreign aid? Mimeo: University of Maryland.

Erbas, N. (2003). IMF conditionality and program ownership: A case for streamlined conditionality. IMF Working Paper 03/98.

Freedom House. (2005). Freedom of the press 2004: A global survey of media independence. MD: Rowman and Littlefield.

Goldberg, B. (2003). Bias: A CBS insider exposes how the media distort the news. New York: Harper Paperbacks.

Goldstein, M. (2000a). IMF structural programs. Paper prepared for NBER Conference on Economic and Financial Crises in Emerging Market Economies, Available at: http://www.iie.com.

Goldstein, M. (2000b). Strengthening the international financial architecture: Where do we stand? Institute for international economics working paper 00-8, Available at: http://www.iie.com/catalog/ WP/2000.

International Monetary Fund. (2001). Conditionality in fund-supported programs-policy issues, Available at: http://www.imf.org/external/np/pdr/cond/2001/eng/policy/index.htm.

Kahn, M., \& Sharma, S. (2001). IMF conditionality and country ownership of programs. IMF working paper $01 / 142$.

Kenen, P. (2000). Financial-sector reform in emerging-market countries: Getting the incentives right. Remarks prepared for the panel discussion on strengthening the resilience of global financial markets sponsored by the Per Jakobsson foundation, Lucerne, Switzerland.

Kuypers, J. A. (2002). Press bias and politics: How the media frame controversial issues. Westport, CT: Praeger Publishers.

Leeson, P. T. (2006). How much benevolence is benevolent enough? Public Choice, 126, 357-366.

Leeson, P. T. (2007). Inside the black box: Media freedom, political knowledge, and participation. mimeo.

Leeson, P. T., \& Coyne, C. J. (2005). Manipulating the media. Institutions and Economic Development, 1, 67-92.

Leeson, P. T., \& Trumbull, W. (2006). Comparing apples: Normalcy, Russia, and the remaining postsocialist world. Post-Soviet Affairs, 22, 225-248.

Meltzer, A., et al. (2000). International Financial Institution Advisory Commission Report. Washington, DC.

Sen, A. (1984). Poverty and famines. Oxford: Oxford University Press.

Sen, A. (1999). Development as Freedom. New York: Alfred A. Knopf Inc. 
Spraos, J. (1986). IMF conditionality: Ineffectual, inefficient, mistargeted. Essays in International Finance, No. 166, Princeton University.

Tullock, G. (1999). Non-prisoner's dilemma. Journal of Economic Behavior and Organization, 39, 455458.

Williamson, J. (2000). The role of the IMF: A guide to the reports, International economics policy brief 00-5, Institute for international economics, Available at: http://www.iie.com/newsletr/news005.htm.

World Bank. (2006). World development indicators Online. 